NEWS

\title{
Mouse patent sparks 'uncivil' spat
}

\author{
Academic institutes lock horns in legal action over mutant mice.
}

The Jackson Laboratory, a non-profit genetics research centre in Bar Harbor, Maine, is embroiled in its first ever patent dispute with another non-profit research institute.

"It is almost unheard of for one academic institute to sue another over patent infringement," says the Jackson Lab's corporate lawyer, David Einhorn, who described the dispute on 21 May at a meeting in Rome on sharing data and resources for functional genomics. "The affair is completely uncivil."

The suit was filed by the Central Institute for Experimental Animals (CIEA) in Kawasaki, Japan, which last week reported the world's first transgenic primate able to pass a foreign gene to its offspring (E. Sasaki et al. Nature 459, 523-527; 2009). In 2006 the CIEA was granted a US patent on a strain of immunodeficient mice called NOG, which it began to make commercially available in the United States earlier this year. The institute has also trademarked the strain.

The CIEA's lawsuit claims that the Jackson Lab is infringing the patent, a claim the laboratory denies. Among the more than 4,000 mouse mutant strains that the Jackson Lab maintains and distributes to the worldwide academic community is a mouse similar to NOG, called NSG. The Jackson Lab developed the NSG strain and, since 2006, has made it available to more than 640 research groups worldwide. It does not patent.

The CIEA says it is after recognition, not profits. "We would like scientists around the world to recognize the innovation involved in the creation of the NOG mouse," says Hideo Maeno, general manager in the institute's strategic management department.

The institute distributes NOG mice under quite restrictive terms: purchasers cannot breed or cross-breed from them, and there are extensive 'reach-through' rights that control successive work done with the mice.

Immunodeficient mice are widely used in the study of diseases such as cancer or diabetes because they can be 'humanized' by having human tissue or human transgenes transplanted into them. As their immune system is suppressed, the mice tend not to reject the foreign tissue.

In the 1980s, an immunodeficient mouse strain called CB17-SCID was generated by a spontaneous mutation. In the 1990s, this SCID mutation was crossed first by scientists at the Jackson Lab, and later at the CIEA, with their respective strains of another, non-obese diabetic (NOD) mouse.

The Jackson Lab and the CIEA then each independently crossed their NOD-SCID strains with mice whose gene for a key immune signalling molecule, IL2R $\gamma$, was either partially or completely knocked out. The NOD-SCID IL2R $\gamma$-deficient mice - abbreviated as NOG by the CIEA and as NSG by the Jackson Lab - are particularly good at accepting grafted tissue.

The Jackson Lab denies that it has infringed any patent or trademark rights. Einhorn notes that the long-established NOD and SCID strains used to create the mice were not identical anyway, because of natural genetic drift accumulated over many generations in the separate locations.

\section{Funding struggle for mercury monitoring}

Nicola Pirrone may need all the help he can get next week. In the hallways of a conference in Guiyang, China, Pirrone - the director of Italy's CNR-Institute for Atmospheric Pollution Research - will be trying to rustle up support for a global network to monitor mercury pollution.

Such a network would underlie a United Nations Environment Programme (UNEP) treaty to control mercury emissions, which negotiators plan to forge by 2013. So far, countries from Mexico to South Africa to Japan have expressed interest in setting up a monitoring system. But to turn interest into reality, researchers are facing a complex task on what may be shoestring budgets.

Anthropogenic sources emit about 2,500 tonnes of mercury
GLOBAL MERCURY EMISSIONS
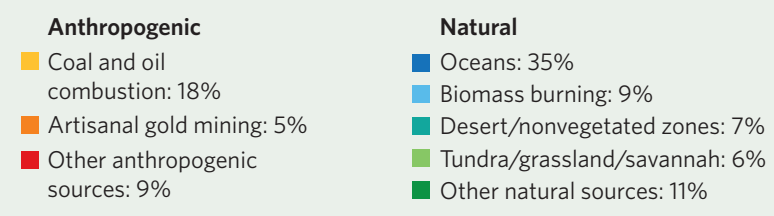

ources: $9 \%$

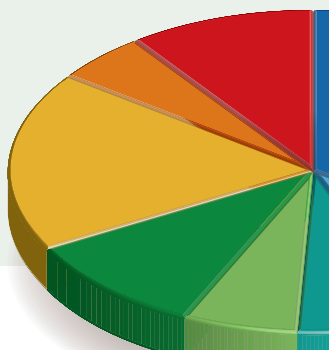

every year, more

than half of which comes from fossil-fuel power plants (see chart). But so far, global monitoring endeavours have been relatively uncoordinated; hundreds of stations that can monitor mercury deposition at a high enough precision over the long term to be useful in a treaty. These include sophisticated monitors made by Tekran Instruments Corporation in Knoxville, Tennessee, which can collect mercury from both rainfall and dry air and determine its chemical form.

US researchers have been working to combine data from about a dozen Tekran-equipped sites, along with other longer-term studies, into a national monitoring effort called MercNet that could serve as a starting point for a global network. Some initial high-quality worldwide data are starting to become available, for instance from Taiwan's Changbai Mountain (Q. Wan et al. Environ. Res. 109, 201-206; 2009).

But expanding the number of 


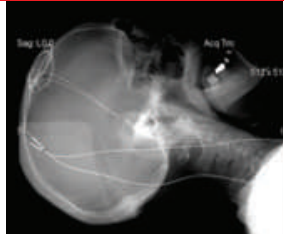

ELECTRODES SPARK NEURON GROWTH

Deep-brain stimulation could help make memories. www.nature.com/news

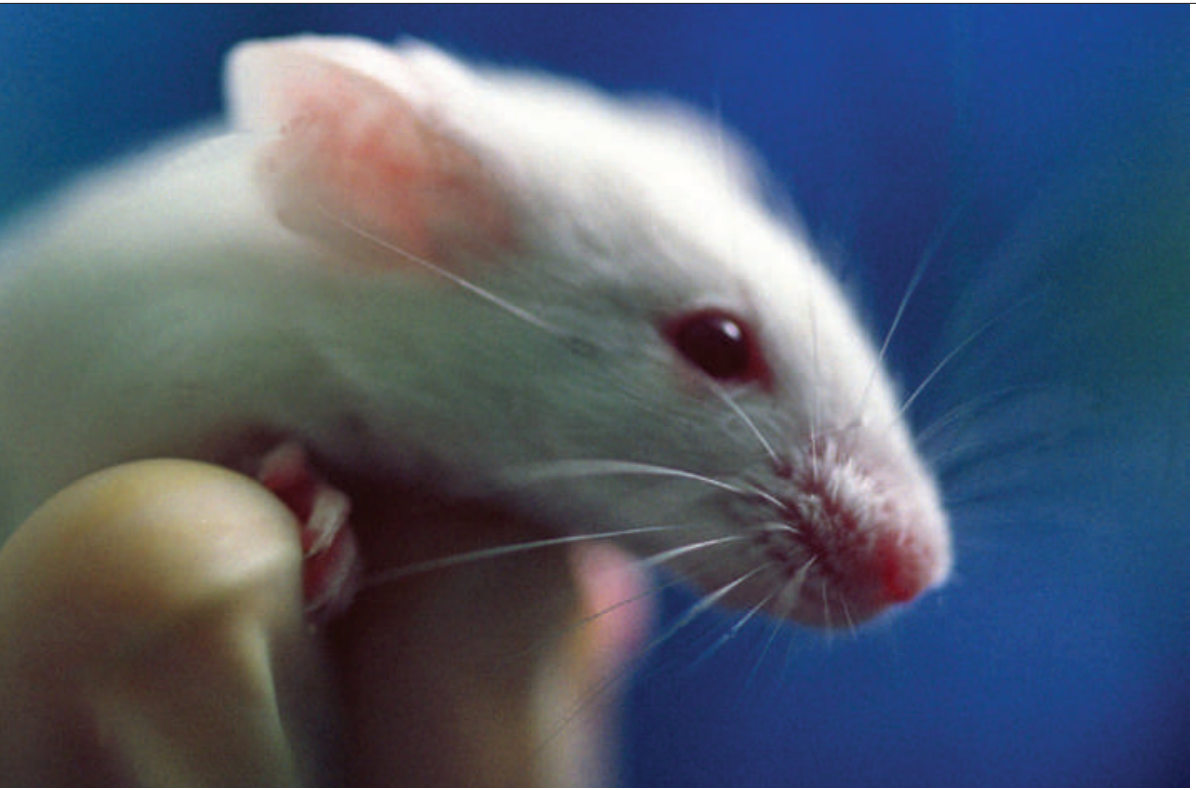

Handle with care: more than 4,000 strains of mice are produced at the Jackson Laboratory.

Einhorn is particularly upset that the CIEA did not contact the lab about its concern before filing the case in December in a US district court in northern California. "The first I heard was three days later when I got a call from a Californian lawyer who had spotted the case and was offering us his services," he says.

Maeno did not respond directly to ques- tions about why his institute didn't contact the Jackson Lab before filing suit. But, he says, "we have enjoyed a close relationship with the Jackson Lab in the past and we hope to continue that relationship in the future."

The National Institutes of Health, which funds the Jackson Lab repository, has asked the lab to bring a counterclaim on its behalf, saying that the CIEA infringed a patent it filed on the knockout mouse used to breed both the NOG and NSG strains. The NIH patents biological inventions to prevent others from patenting $\underset{\sim}{\stackrel{4}{c}}$ and then restricting use.

Jackson Lab scientist Leonard Shultz, who has worked for 35 years on developing humanized mice including the NSG strain, echoes the concerns of many in the community when he says he does not understand the CIEA's motivation. The CIEA says it cannot comment concretely on such matters, because of the ongoing litigation.

On face value, the CIEA does not seem like an aggressively modern, lawyer-wielding institute. It is more old-world, with its rundown buildings tucked into a modest residential area of the working-class city of Kawasaki.

It is still directed by 87 -year-old Tatsuji Nomura, the infectious-disease researcher who founded it in 1952 because he was concerned about the variable quality of research animals. It is operated by a foundation funded by some 30 Japanese pharmaceutical and biomedical companies.

"Science is essentially a global enterprise and national profit is not part of our mindset," insists Maeno. "We are absolutely not trying to slow the pace of science."

Alison Abbott

Additional reporting by David Cyranoski sites globally will be expensive. A top-of-the-line Tekran monitor costs about US $\$ 100,000$, not including operational costs. On top of that, mercury researchers would like to see a host of other measurements, including regularly scheduled aeroplane monitoring high in the troposphere to see how chemical reactions change airborne mercury; research cruises to measure what is happening in the ocean-air boundary layer; and more data on mercury levels in the oceans themselves.

One money-saving option might be to piggyback mercury measurements on other sites that already collect atmospheric data, says Robert Mason, an environmental chemist at the University of Connecticut in Groton. Mason is advising researchers who are working to set up a network in China, Japan and Korea, including expanding existing stations.

But some researchers worry that the focus on air monitoring may mean that other parts of the environment get overlooked. "There has to be a biological component to this," says David Evers of the BioDiversity Research Institute in Gorham, Maine. That could mean, for instance, identifying 'hot spots' that receive airborne mercury and turn it into a form that could be taken up by fish and then humans.

Pierrette Blanchard, an atmospheric chemist at Environment Canada, notes that even fish in seemingly pristine lakes in national forests in the United States and Canada can contain high levels of mercury.

In particular, Evers wants to see estuarine and marine sampling in the Amazon basin, where smallscale gold mining releases mercury into environments where fish are caught for food. He and his colleagues have also proposed a marine and estuaries network for monitoring the US Atlantic coast.

And Evers and others have been advising Senator Susan Collins (Republican, Maine) on a bill that would provide funding from the US Environmental Protection Agency for a national mercury network to include air, water, soils and animals. Collins has tried several times before; in 2007, for instance, she requested that $\$ 18$ million be designated, but the effort died at the committee stage. Collins hopes to reintroduce the bill this summer.

The costs of an international monitoring system are unknown, and will depend on how much various countries are willing to put up for equipment and staffing. That may be a point for discussion when negotiations for the UNEP treaty begin in earnest early next year. The talks have been boosted by the United States, which had long called for voluntaryonly mercury monitoring but in February indicated it would support an international regulatory structure. "What we need to do is to inform the negotiations," says a US state department official who requested anonymity because of the talks.

Bettina Hitzfeld, a UNEP negotiator for the Swiss Federal Office for the Environment, says that treaty discussions need to start moving ahead even in the absence of a complete monitoring system. "We cannot afford to wait," she says, "for a mercury network to be up and running."

Naomi Lubick

\section{HIN1 update}

As confirmed by the World Health Organization, as of 1 June: Cases: 17,410 , in 62 countries Deaths: 115 , in 4 countries

UNITED STATES: Cases have now been documented in all 50 states.

For Nature's swine flu coverage, see www-nature.com/swineflu. 


\section{Editor to quit over hoax open-access paper}

The editor-in-chief of an open-access journal is to resign after claiming that its publisher, Bentham Science Publishing, accepted a hoax article without his knowledge.

Bambang Parmanto, an information scientist at the University of Pittsburgh, Pennsylvania, and editor-in-chief of The Open Information Science Journal, said he had not seen the computer-generated manuscript, accepted by Bentham on 3 June.

The fake paper was submitted by Philip Davis, a graduate student in communication sciences at Cornell University in Ithaca, New York, and Kent Anderson, an executive director at The New England Journal of Medicine. Davis says he wanted to test if the publisher would "accept a completely nonsensical manuscript if the authors were willing to pay". He retracted the paper after being notified that it had been accepted, and that he should pay US $\$ 800$ to Bentham's subscription department.

Mahmood Alam, director of publications at Bentham Science Publishing, told Nature that "submission of fake manuscripts is a totally unethical activity and must be condemned", adding that "a rigorous peerreview process takes place for all articles that are submitted to us for publication". For a longer version of this story, see http://tinyurl.com/Irx6m6

\section{FDA gains the power to regulate tobacco products}

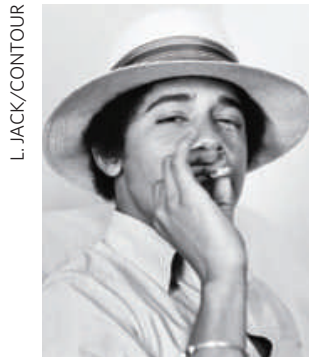

Obama in his youth.
The US Food and Drug Administration (FDA) will get the power to regulate tobacco for the first time in its 103year history under legislation passed by Congress last week. President Barack Obama, himself a sometime smoker (see picture), has promised to sign the bill into law.

Passed by substantial majorities in both the House and the Senate, the Family Smoking Prevention and Tobacco Control Act requires that new tobacco products win pre-market approval from the FDA.

The bill bars the FDA from banning nicotine, but it gives the agency standardsetting authority that could lower nicotine levels in tobacco products. It constrains advertising, requires large warning labels on packaging and levies user fees paid by the industry to help finance FDA regulation. The fees will total \$235 million in 2010.

\section{Infrared scan reveals colourful past of the Parthenon}

Conservation scientists at the British Museum in London have found the first evidence of coloured pigments on sculptures from the Acropolis in Athens. The figures formed part of the decoration on the Parthenon temple, and were taken from Greece by Lord Elgin in the early 1800s.

Ancient Greeks and Romans normally painted their sculptures, and traces of the pigments tend to survive on the objects to this day. But no hints of paint had been found on the Parthenon sculptures despite detailed studies - including an analysis in the 1830 s by English physicist Michael Faraday.

The researchers revealed the presence of a pigment known as Egyptian blue on the belt of the goddess Iris (pictured).

They used a portable detector to beam red light onto the surface and capture the infrared light emitted by the luminescent pigment particles (inset).

For a longer version of this story, see http://tinyurl.com/m24ylw
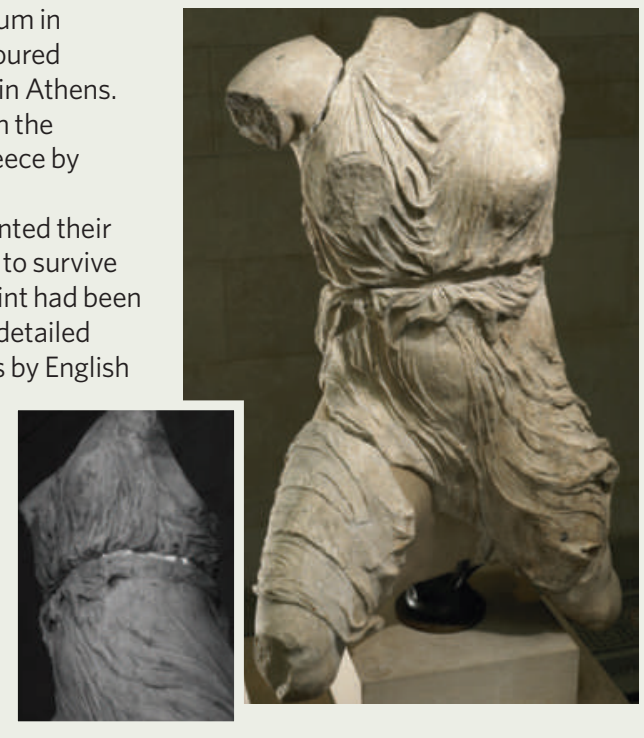

\section{Japan's lunar orbiter ends mission with crash landing}

The Japanese space agency's KAGUYA lunar orbiter ended its 21-month mission with a planned crash into the Moon on 10 June.

Formally known as SELENE

(Selenological and Engineering Explorer), the mission was launched in September 2007. The orbiter gathered detailed geological information about the Moon, mapping its gravitational field and taking high-definition video images.

As Nature went to press, NASA's Lunar Reconnaissance Orbiter was scheduled to launch on 18 June. Together with India's Chandrayaan-1 spacecraft, which launched in October 2008, it will attempt to spot water ice at the Moon's poles (see Nature 459, 758-759; 2009).

\section{Artefact raiders charged after undercover operation}

A two-year federal investigation of widespread Native American grave robbing and artefact theft in the Four Corners region of the United States culminated in charges against 24 people last week.

The arrested individuals, from Utah, Colorado and New Mexico, were arraigned in the federal court on 10 and 11 June for multiple felony indictments for trade in 256 artefacts with a total value of more than US\$335,000. Purloined items included pottery, baskets, sandals and necklaces taken from excavations on federal lands.

An undercover agent purchased the looted artefacts from, among others, a high-school teacher and an honoured archaeologicaltourism promoter. One man - James Redd, a physician from Blanding, Utah committed suicide on 11 June, authorities say, the day after he and his wife were charged with artefact theft.

\section{US revives FutureGen 'clean' coal plant}

The US Department of Energy (DOE) has announced plans to revive FutureGen, a commercial-scale coal-fired power plant in Mattoon, Illinois, that would capture carbon dioxide emissions and sequester them underground.

Under George W. Bush's administration, the DOE pulled the plug on the flagship 'clean' coal technology programme in January 2008, citing a dispute with industry partners over the US\$1.8-billion price tag (see Nature 451, 612-613; 2008).

Energy secretary Steven Chu revived FutureGen on 12 June, announcing an agreement to restart the negotiations, update the cost estimate and begin preliminary design activities. The DOE and FutureGen industry partners hope to make a final decision on whether to go ahead with the project early in 2010.

\section{Corrections}

The News Feature 'Sucking it up' (Nature 458, 1094-1097; 2009) incorrectly stated that Global Thermostat is waiting for venture-capital funding to build a prototype for the capture of $\mathrm{CO}_{2}$ from the air. It already has sufficient funding in place.

The News story 'Funding struggle for mercury monitoring' (Nature 459, 620-621; 2009) erroneously located Changbai Mountain in Taiwan. It is in northeastern China.

In the News Feature 'Nascence man' (Nature 459, 316-319; 2009), the picture of the Lost City on page 318 should have been credited to D. S. Kelley. 